\title{
SEMI-CURVED BUCKLING MODES AS A RESULT OF THE OPTIMIZATION OF COMPRESSED RODS
}

\author{
Bekshaev S. \\ s.bekshayev@gmail.com, ORCID: 0000-0002-5752-5321 \\ Odessa State Academy of Civil Engineering and Architecture \\ 4, Didrikhson street, Odessa, 65029, Ukraine
}

\begin{abstract}
We are looking for such positions of the intermediate absolutely rigid hinge support of the two-span rod at which its first critical force reaches its maximum. The one end of the rod is supported on an absolutely rigid support, and in addition is elastically or rigidly built-in. The second end is pivotally supported on an elastic support of finite stiffness. The bending stiffness of the rod varies along its length according to an arbitrary law. The compressive force in all sections of the rod is the same. It was established that the qualitative characterization of the positions sought, as well as the corresponding critical forces and buckling modes, depend on the stiffness characteristics of the elastic constraints at the ends of the rod. Three ranges of varying in the values of the stiffness coefficient of the end support are determined, which correspond to qualitatively different solutions to the problem. For the lowest of them, the optimal position is the end of the rod, supported by an elastic support. For the middle range, the optimal position is the intermediate cross section of the rod, in which the bending moment at buckling is zero. This position separates a fragment resting on an elastic support, which deforms when it buckles, like an insulated rod hinged at its ends on absolutely rigid supports. The rest of the rod at buckling remains undeformed. Thus, with the values of the stiffness coefficient of the end elastic support from the middle range, the most stable twospan rod buckles in a special semi-curved mode. For the third, higher range, the optimal position is the node of the second buckling mode of the rod formed from original rod by remove the intermediate support. The sought maximum of the critical force is equal to the second critical force of the single-span rod freed from the intermediate support. The results of the work are obtained on the basis of the systematic use of qualitative methods of the rod systems theory stability, in particular, relating to the influence of setting of constraints on critical forces. They can be used in the design and operation of engineering structures containing compressed members.
\end{abstract}

Keywords: buckling, compressed rod, semi-curved mode, optimization.

Introduction. Providing the stability of the compressed elements of engineering constructions is the important factor of their reliable and safe exploitation. One of effective ways of this task solution is strengthening of these elements by setting and rational placing of additional intermediate supports. It is thus necessary to search such positions of the entered supports that provide the maximal value of critical force (further - CRF) of the compressed element. It is known that, for example, for a longitudinally compressed rod, pivotally supported at the ends by rigid supports, reinforced by one intermediate support, this position is the node of the buckling mode (hereinafter - BM), which corresponds to the 2nd in the spectrum of the CRF of the rod before strengthening. In general, as a rule, nodes of BM are positions that provide an extremum of the CRF of a rod reinforced by hinged supports placed in these nodes $[1,2]$. However, at the same time, maximum stability is not guaranteed, for which it is required that the specified extremum be just the maximum and just the fundamental (smallest) CRF. It may happen that even in the presence of BM nodes, the maximum CRF will be provided at other positions of the installed supports.

Analysis of recent research. In [3, 4], it was considered and qualitatively described the determination of such a position of the intermediate hinge support of a two-span rod, one end of which is supported by an elastic support (Fig. 1,a), at which its CRF reaches its maximum. It has been found that at certain values of the stiffness of this support, the maximum of the main CRF is achieved at such 


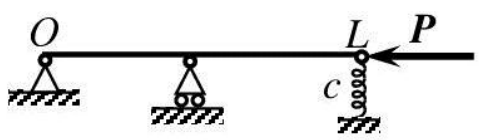

a)

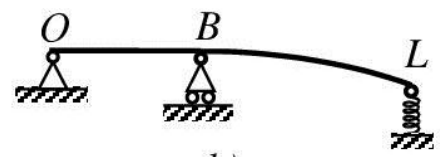

b)

Fig. 1. Two-span rod $(a)$ and its semi-curved BM $(b)$

a position of the internal support, which corresponds to a semi-curved BM (Fig. 1, b), which has an undeformed fragment on one side of this support. CRF corresponding to it is equal to the CRF of the rod $B L$ hinged at the ends on absolutely rigid supports, and at the same time equal to $c \cdot|B L|$, where $c$ is the stiffness coefficient of the elastic support.

As you can see, this BM will not be perturbed if a rigid or elastic clamp will be installed on the left support. This suggests that in these cases, semi-curved BMs will retain their extreme properties and will provide the maximum increase in CRF.

The aim of the work is to determine the position of the intermediate rigid hinge support of a two-span rod $S$, at which its main CRF reaches a maximum, provided that one of its end supports has finite stiffness $c$, and elastic or rigid clamp is set on the other (Fig. 2, a). The bending stiffness of the rod can vary along its length according to an arbitrary law. The compressive force in all sections of the rod is the same.

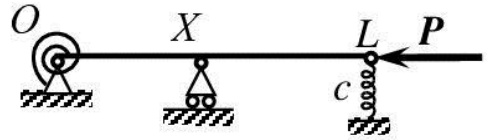

a)

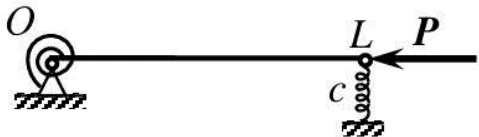

b)

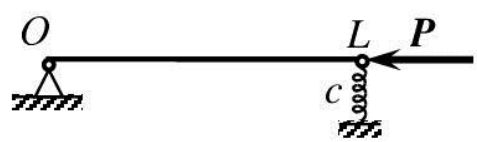

c)

Fig. 2. Rod $S$ to be optimized $(a), \operatorname{rod}\left[O L(b)\right.$ and $\operatorname{rod} S_{0}(c)$

Research Methodology. The results are obtained mainly using qualitative methods. In particular, the well-known result on the behavior of CRF when setting constraints is systematically used [1, Ch. V]:

A. The setting of one constraint does not lower any of the CRF, but does not make it higher than the CRF of next number in the spectrum. The reach of the latter is possible only when constraint is set just in the node of the corresponding BM.

The following a s u m ption is also accepted:

B. If in a single-span rod obtained from $S$ by removing the intermediate support and replacing the elastic support with absolutely rigid one, to cut off some part at the right or left, and apply the previous conditions of support to the remaining part, then at least two lower CRF will increase.

This fact is well known for prismatic rods under standard support conditions, moreover, for the CRF of all numbers. However, with an arbitrary distribution of bending stiffness along the length of the rod, this assumption may not be satisfied. In rods with extended sections of high rigidity, alternating with relatively short and flexible elements, the described shortening from the side of the hinged support in the presence of clamp on the opposite can lead not to growth, but to a decrease in CRF [5]. In most practical situations, compressed rods (racks, columns) have a relatively smooth change in bending stiffness along the length that does not break the qualitative properties of prismatic rods, in particular, of their lowest CRFs. Therefore, Assumption B does not significantly limit the practical significance of the results obtained in this work.

We note some sufficient conditions under which assumption B is certainly valid.

C. For a rod hinged at the ends on rigid supports, when removing any part of rod and setting the formed free end on the previous support, all CRFs increase. 
To verify this, we make a cut and insert a hinge in some inner section of the rod, which is equivalent to removing one constraint. At the same time, based on A, all CRFs will decrease, but not lower than the previous one in the spectrum. The second CRF of the formed compound rod coincides with the $\mathrm{CRF}$ of one of the two formed parts, whence statement $\mathrm{C}$ follows from $\mathrm{A}$.

Consequence of $\mathrm{C}$. For any distribution of bending stiffness along the length of the rod, there is a certain range of clamp stiffness values under which assumption $C$ is satisfied.

Indeed, if, at zero stiffness of the clamp the CRF of a shorter rod is higher than the CRF of a longer one, then as the stiffness increases, this inequality will not be broken instantly, but will satisfy until the stiffness reaches a certain limit.

The wider sufficient conditions for validity of assumption B are established in [5].

Remark. Further, the stiffness coefficient of the clamp is considered arbitrary. In Fig. 3-5, the rigid clamp on the support $O$ can be mentally replaced by elastic.

The results of the study. The following notation is used:

$(X Y)$ - single-span rod hinged at the ends $X$ and $Y$ on absolutely rigid supports;

$[X Y)$ - rod formed from $(X Y)$ by setting of clamp in section $X$;

$[X Y-$ rod formed from $[X Y)$ by replace of rigid support in $Y$ by elastic one with stiffness coefficient $c$;

$[O X L$ - a two-span compound rod formed from $[O L$ by setting of a rigid hinged support and cutting in the intermediate section $X$;

$\ell=|O L| ; P(*), P[*), P[*-$ fundamental (smallest) CRF of rod $(*)$, respectively $[*),[*$;

$P_{1}=P, P_{2}, \ldots-$ CRFs of rod $[O L$ (Fig. $2, b)$ in ascending order;

$P_{1}^{0}, P_{2}^{0}, \ldots-$ CRFs of rod $(O L)$ in ascending order.

1. First, we establish some properties of the BM and the corresponding CRF of a single-span $\operatorname{rod}[O L($ Fig. 2, b).

1.1. The rod $[O L$ is formed by installing one constraint in the form of clamp at the left end from the rod $S_{0}$ hinged at the ends shown in Fig. 2, $c$. The spectrum of the latter contains all CRFs of the rod $(O L)$ and one else special CRF, equal to $c \ell$ which corresponds to the rectilinear BM. From the statement A above, in particular, it follows that if $P_{j}^{0} \leq c \ell \leq P_{j+1}^{0}$, then $P_{j}^{0} \leq P_{j} \leq c \ell \leq P_{j+1}^{0}$ and $P_{j}^{0} \leq c \ell \leq P_{j+1} \leq P_{j+1}^{0}$.

1.2. All CRFs of rod $[O L$ are simple. Otherwise, for some CRF, there would be two linearly independent distributions of bending moments along the length, from which we could linearly compose a distribution with a zero derivative of the moment on the support $L$, what, since the moment itself on this support is equal to zero, would mean that the composed distribution is identical zero, i.e., that these distributions are linearly dependent.

1.3. When $c<P_{1}^{0} / \ell$ the first BM (Fig. 3, $a$ ) has no nodes, i.e. points, which deflection is zero.

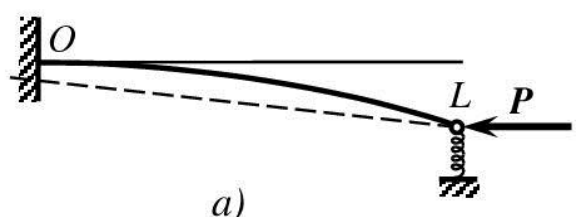

a)

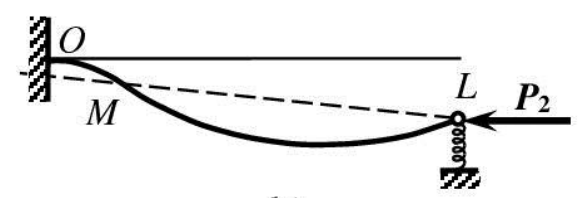

b)

Fig. 3. First $(a)$ and second $(b) \mathrm{BM}$ rod $\left[O L\right.$ when $c<P_{1}^{0} / \ell$

This follows from the fact that at buckling, the moment of the resultant compressive force $\boldsymbol{P}$ and the reaction of the elastic support about $O$ is equal to $(c \ell-P) f$, where $f$ is the transverse displacement of the point $L$, and $P$ by virtue of A satisfies the inequalities $c \ell<P<P_{1}^{0}$. 
Geometrically, this means that the line of action of this resultant (dashed line), when the right end of the rod displace down, passes below the clamped section $O$, as a result of which the neighborhood of this section is convex upward. The main BM does not have inflection points (where the bending moment is zero), because otherwise it would be $P=P(M L)>P_{1}^{0}$, where $M$ is the inflection point, since $(M L)$ is obtained from $(O L)$ by a shortening causing an increase in CRF (see statement $\mathrm{C}$ above).

The second BM (Fig. 3, b), for which $c \ell<P_{1}^{0}<P_{2}<P_{2}^{0}$, has one inflection point $M$, because otherwise $P_{2}$, equal to one of the higher CRF of the rod $(M L)$ obtained from $(O L)$ by shortening, would be higher then $P_{2}^{0}$. Moreover, as can be seen from Fig. 3, $b$, the second BM has no nodes.

1.4. When $c>P_{1}^{0} / \ell$ the first BM (Fig. $4, a$ ) has one node $A$, because now the dashed line of

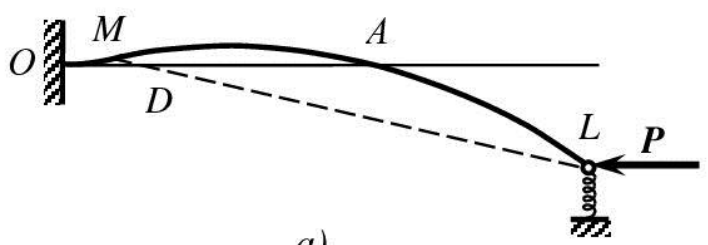

a)

Fig. 4. 1st BM of a rod $\left[O L\right.$ at $c>P_{1}^{0} / \ell(a)$ and 2 nd BM of a rod $\left[O L\right.$ at $c=P_{2}^{0} / \ell(b)$

action, due to the relations $P_{1}^{0}<P=P(M L)<c \ell$, passes above the clamped section $O$, which guarantees the existence of an inflection point $M$ of the axis of the rod located above its equilibrium position. Two or more inflection points cannot exist, because then it would be $P=P(M L)>P_{j}^{0}$ for some $j \geq 2$ (due to shortening, see statement $\mathrm{C}$ ), which contradicts the requirement $P<P_{2}^{0}$ (Sec. 1.1).

Remark. Inequality $c>P_{1}^{0} / \ell$ is a condition for the existence of a node $A$ and simultaneously is a condition for the existence of a semi-curved BM (Fig. 1,b) of the rod $S$ [3] when the rigid hinge support is installed at a point $B$ for which the CRF is equal to $c \cdot|B L|=P(B L)$, moreover, as a result of setting constraint $c \cdot|B L|>P=c \cdot|D L|$ ( $D$ - the point of intersection of the dashed line with the horizontal in Fig. 4,a). It follows that $|B L|>|D L|$, i.e. the point of conjugate $B$ of the semi-curved BM is located to the left of $D$ (for the main BM of the rod $S$, corresponding to CRF equal to $c \cdot|D L|$ ).

For the sec ond $\mathrm{BM}$, when $P_{1}^{0} / \ell<c<P_{2}^{0} / \ell$, remains valid everything that is said about $\mathrm{BM}$ in Fig. 3, $b$, in particular the absence of nodes. At $c=P_{2}^{0} / \ell$ (Fig. 4, b) the equalities $P_{2}=P_{2}^{0}=c \ell=P(M L)$ are satisfied, from which it follows that the dashed line passes through the clamped section $O$ and the 2nd BM has an internal inflection point $M$ and zero bending moments in the sections $O$ and $L$. This BM is the 2 nd BM of the rod $(O L)$, rotated so that the clamp reaction on the support $O$ vanishes. When $c>P_{2}^{0} / \ell$, as follows from the conclusions of Section 1.1 , the inequalities $P_{2}^{0}<P_{2}=P(M L)<c \ell$ are satisfied, from which it follows that the dashed line (Fig. 5) passes above the clamped section $O$ and the 2nd BM has two inflection points $M$ and $M_{1}$,
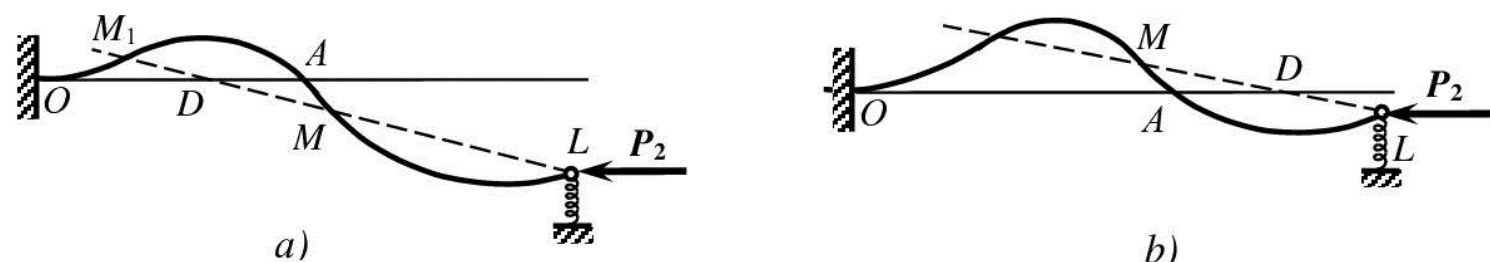

b)

Fig. 5. 2nd BM of a rod $\left[O L\right.$ at $c>P_{2}^{0} / \ell$ 
since now, by virtue of formulated above Statement C, $P_{2}$ is equal to the 2 nd CRF of the shortened $\operatorname{rod}\left(M_{1} L\right)$. If there were more than two inflection points, incompatible inequalities $P_{2}>P_{3}^{0}$, $P_{2}<P_{3}^{0}$ would have to be satisfied. At two inflection points, as one can see from Fig. 5, 2nd BM has a single node $A$.

1.5. Let us introduce a number of constants characterizing the system under consideration and independent of the coefficient $c$.

Denote by $H$ the point of the rod for which there holds the equality $P(H L)=P[O L)$, i.e. the point cutting off segment $(H L)$ equally stable (when hinged on rigid end supports) to the entire rod $[O L)$ hinged on rigid support at $L$.

$E$ is a point defined by equality $P(E L)=P[O E)$. It divides the rod $[O L)$ into two equally stable parts $[O E)$ and $(E L)$ (with absolute rigidity of the hinged supports in $E$ and $L$ ). By virtue of assumption $\mathrm{B}$, the point $E$ is unique.

$P(E L)=P[O E)$ is a 2-multiple CRF of a compound rod formed from the $[O L)$ by cutting and setting of the hinge support in the section $E$. After setting a constraint that eliminates the cut, it remains CRF, but already simple, of the rod obtained from the $[O L)$ by installation of the support in $E$, increasing CRF. Therefore $P(E L)>P[O L)=P(H L) \Rightarrow$

$$
P(E L)>P(H L) \Rightarrow|E L|<|H L| .
$$

1.6. In cases where the second $\mathrm{BM}$ has a node $A$ (at $c>P_{2}^{0} / \ell$ ), it can place to the right or left of the inflection point $M$ (compare Fig. 5, $a$ and 5, $b$ ). We establish the following statement.

Criterion of node location. The node $A$ of the second $\mathrm{BM}$ of $\operatorname{rod}[O L$ :

- lies to the left of the inflection point $M$ for $c<P(E L) /|E L|$;

- lies to the right of the inflection point $M$ for $c>P(E L) /|E L|$;

- coincides with the inflection point $M$ when $c=P(E L) /|E L|$;

With growth $c$ from $P_{2}^{0} / \ell$ to $\infty$, the point $D$ of intersection of the dashed line with the horizontal in Fig. 5 (for which $c \cdot|D L|=P_{2}$, because the moment of external forces about $D$ is equal to zero) moves from $O$ to $L$. The fragment $M L$, at the ends of which the bending moments are equal to zero, when buckling deforms like a rod on hinges, which is shortened because the CRF growth due to growth of $c$. Therefore, the point $M$ moves monotonously to the right, but within the limits restricted by the node of the second $\mathrm{BM}$ of the $\operatorname{rod}(O L)$ (when $c=P_{2}^{0} / \ell$ ) and the position for which $P(M L)=P_{3}^{0}$ (since $P_{2}^{0} \leq P_{2} \leq P_{3}^{0}$ ). Obviously, at some $c$ these points, and with them the node $A$, which, as one can see from Fig. 5, $a$ and 5, $b$, lie between $M$ and $D$ must coincide. We prove that this happens only once, i.e. at the single value of $c$. The point $M$ when coincides with $D$ is the node $A$ of the 2 nd BM of the rod $[O L$ and divides the rod into two equally stable parts $[O A)$ and $(A L)$. This follows from the fact that when they buckle under the action of force $P_{2}$, each of them deforms as an independent rod, supported at a point $A$ on a rigid hinge. Therefore, the point $M=D=A$ of «triple coincidence» must satisfy the condition $P(M L)=P[O M)$, whence it follows that it is the point introduced earlier in sec. 1.5 and the only single, as follows from its definition. The corresponding value of the stiffness coefficient is equal to $c=P(M L) /|D L|=P(E L) /|E L|$, whence the validity of the criterion follows.

R e mark. When $c=P(E L) /|E L| \mathrm{CRF}$ of the right side of the compound rod $[O E L$ is equal to $P(E L)=c \cdot|E L|$ and is 2-multiple, since in addition to the main $\mathrm{BM}$ of the $\operatorname{rod}(E L)$, it also corresponds to the rectilinear BM of the fragment $E L$, rotated about $E$ due to vertical displacement 
of the support $L$. Therefore, in the spectrum of the entire rod $[O E L$, together with the CRF $P[O E)=P(E L)$ of the left part, it is 3-multiple. After imposing a constraint that eliminates the cut in the section $E$ and forms the rod $S$, it becomes 2-multiple. The corresponding BMs can be selected semi-curved. One of them has the form shown in Fig. 1, $b$. The second represents a special case of a semi-curved BM, when the right part is inclined, remaining straightforward.

2. Studying the influence of the position of the support on simple CRFs of multi-span rods, we use the relation [2]:

$$
P^{\prime}=R \theta,
$$

where $P^{\prime}$ is the derivative of simple CRF with respect to the coordinate equal to the distance of the support from the left end of the rod, $R$ is reaction of support (positive when acting upward), $\theta$ is the slope of the section of BM (positive when the section inclines clockwise) above the support (with the corresponding normalization).

The solution to the problem of finding the optimal location of the intermediate support is presented in the following statements.

2.1. When $c<P[O L) /|H L|=P(H L) /|H L|$ the maximum of CRF of the $\operatorname{rod} S$ is achieved when installing the support on the right end $L$ of the rod and is equal to $P_{\max }=P[O L)<P_{2}$.

To prove this, we note that when a rigid support is installed at a point $L$ and its reaction direct upward $(R>0)$, the bent axis of the rod at buckling by the first BM (with one inflection point) places wholly above its equilibrium position, whence $\theta(L)>0$ and according to (2) $P^{\prime}>0$. Therefore, the CRF when the support moves to the left of $L$ (in the direction of decreasing coordinates) decreases. Inside the segment $O L$, there may exist extremal positions of the support, in which, according to (2), $R$ either $\theta$ vanishes.

With the restriction on value of $c$ noted at the statement 2.1, taking into account (1):

$$
c<P[O L) /|H L|=P(H L) /|H L|<P(E L) /|E L| .
$$

Therefore, according to the criterion of Sec. 1.6, the node $A$ of the second BM of the rod $[O L$ (if exist) is located to the left of the inflection point $M$ (Fig. 5, a). Let us prove that in this case, when the support is installed in $A$ the $\mathrm{CRF}$ of the $\operatorname{rod} S$ will smaller than $P_{2}$. We form a compound rod $[O A L$ with a hinge support in $A$. Spectrum of its CRF includes the spectrum of the right-hand part, which consists of all the CRF of the rod $(A L)$ and one especial CRF, which is equal to $c \cdot|A L|$ and which corresponds to a straight-line BM. From inequality $|A L|>|M L|$ follow relations $P(A L)<P(M L)=P_{2}=c \cdot|D L|$ and $c \cdot|A L|<c \cdot|D L|$. This means that in the spectrum of the rod $\left[O A L\right.$ there are at least two CRF, smaller than $P_{2}$. One constraint eliminating the cut in section $A$ can increase the CRF to no more than the second, whence CRF of $S$ is less than $P_{2}$. It follows that the second BM of the rod $[O L$ with the node in $A$ cannot correspond to the main CRF of the rod $S$. Therefore, if in some position of the intermediate support when the rod $S$ buckles at the main BM, it occurs that $R=0$ this means that the support is placed in the node of the first BM of the rod $\left[O L\right.$ and the CRF has a minimum equal to $P_{1}$.

If in some position of the support it occurs that $\theta=0$ and the rod is deformed on both sides of support, then the corresponding BM is also not the fundamental one. To verify this, we set in the section under consideration a constraint in the form of a rigid clamp that does not influence the BM. This constraint makes the corresponding CRF 2-multiple, which corresponds to the BMs, remaining on one side of the support undeformed and horizontal. It follows that before the clamp was installed, there should have been a smaller CRF, which was the main one.

Thus, equality $\theta=0$ in the case of the main CRF can only be realized on a semi-curved BM (Fig. 1, b) when the support is installed at the point $B$ of its conjugation and (see the remark in 
Section 1.4) only if there is a node $A$ of the main BM of the rod $[O L$ that lies to the right of $D$ (Fig. 4, a), and therefore to the right of $B$. At this case, CRF has a local maximum equal to $P(B L)=c \cdot|B L|$, and there hold relation $P(B L) /|B L|=c<P(H L) /|H L|$ whence it follows that $B$ lies to the left of $H$, so this maximum is equal to $P(B L)<P(H L)=P[O L)$. Statement 2.1 is proved.

2.2. At $P[O L) /|H L|<c<P(E L) /|E L|$, the maximum $\mathrm{CRF}$ of the $\operatorname{rod} S$ is achieved when the support is installed at the point $B$ of conjugation of the semi-curved BM (Fig. 1, $b$ ), located between sections $H$ and $E$ (see Section 1.5), and is equal to $P_{\max }=P(B L)=c \cdot|B L|<P_{2}$.

To prove this, we note that under the restrictions on $c$ specified in the formulation, the node $A$ of the second BM of the rod $[O L$ is located to the left of the inflection point $M$ (Fig. 5, a).

Since $c>P[O L) /|H L|>P_{1}^{0} / \ell$, the rod $S$ has a semi-curved BM with corresponding CRF equal to $P(B L)=c \cdot|B L|$. Just as in the proof of Statement 2.1, we see that to the right of the conjugation point $B$ there is only one extremum point of the main CRF - this is the node of the first $\mathrm{BM}$ that provides a minimum of CRF. To the right of it there is an increase of CRF, because nowhere else $P^{\prime}$ does equal to zero, but in this case, CRF can only reach a value $P[O L)=P(H L)<c \cdot|H L|$. The last inequality means that the «root» $B$ of the equation $P(X L)=c \cdot|X L|$ defining a semi-curved $\mathrm{BM}$ lies to the right of $H$, whence follows $P(B L)>P(H L)=P[O L)$. In the same way, from $c<P(E L) /|E L|$ it follows that $B$ lies to the left of $E$. The node of the 2 nd BM of the rod $[O L$ cannot be a position providing a maximum of the CRF of the $\operatorname{rod} S$, which proves in the same way as in section 2.1. Therefore, except $B$, there are no points to the left of the node of the 1 st $\mathrm{BM}$ of the $\operatorname{rod}\left[O L\right.$, where $P^{\prime}=R \theta=0$. As one can see from Fig. 5, ac $c|D L|=P_{2}=P(M L)>P(D L)$. It follows that the «root» $B$ of the equation $P(X L)=c \cdot|X L|$ lies to the right of $D$ and $P(B L)=c \cdot|B L|<c \cdot|D L|=P_{2}$. Statement 2.2 is proved.

2.3. At $c>P[E L) /|E L|$, the maximum $C R F$ of the $\operatorname{rod} S$ is reached when the support is installed in the node $A$ of the second BM of the $\operatorname{rod}\left[O L\right.$ and is equal to $P_{\max }=P_{2}$.

Consider a compound rod $[O A L$ with support in $A$. According to the criterion from section 1.6, $P(A L)>P(M L)=P_{2}, c \cdot|A L|>c \cdot|D L|=P_{2}$, so that all the CRF of the right part $>P_{2}$. For the left part $[O A)$, by virtue of Assumption $\mathrm{B}$, the second CRF is larger than the second CRF of the longer rod $[O L)$, which in turn is larger than the 2 nd CRF of the rod $[O L$ (due to the deformability of the support $L$ ). Thus, in the spectrum of the rod $\left[O A L\right.$ there is exactly one CRF $P[O A)<P_{2}$. After elimination of the cut in $A \mathrm{CRF}$ becomes equal to $P_{2}$. Otherwise (assuming that the main CRF of the rod $\left.S<P_{2}\right) P_{2}$ would not belong to the spectrum of $S$, despite the fact that the support is placed in the node of the corresponding BM. At other positions $X$ of the support (not in $A$ ) the CRF of the rod $S<P_{2}$, because the support does not locate in the node of the 2 nd BM of the rod [OL. Statement 2.3 is proved.

Remark. Considerations of sections 2.2 and 2.3 allow us to conclude that $B$ as the «root» of equation $P(X L)=c \cdot|X L|$, like the node $A$ of the 2 nd BM of the $\operatorname{rod}[O L$, lies between $D$ and $M$.

2.4. The conclusions of the previous section 2.3 remain valid in the extreme case of absolutely rigid hinge support $L(c=\infty)$. However, since it may occur that the second BM of the rod $[O L$ does not have nodes (Fig. 6), this case deserves special consideration. 


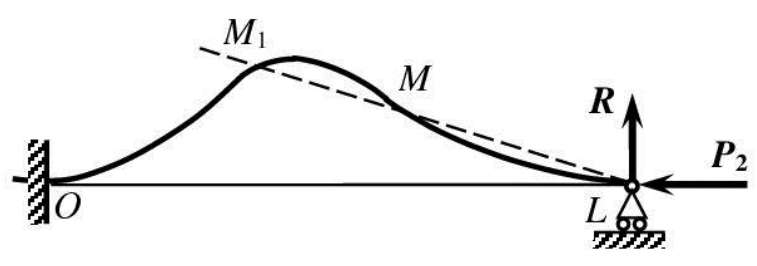

a) $\theta_{L}>0$

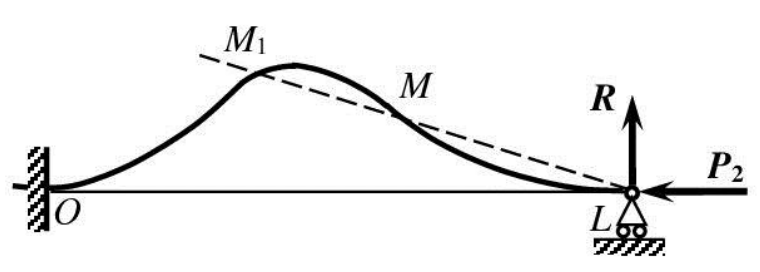

b) $\theta_{L}=0$

Fig. 6. 2nd BM of a rod $[O L$ in the absence of nodes

The end section $L$ can be turned clockwise, $\theta_{L}>0$ (Fig. $6 a$ ), or have a zero slope, $\theta_{L}=0$ (Fig. 6, b). Under the assumptions accepted in the work, the case $\theta_{L}>0$ cannot be realized. This follows from the fact that, as was established in [6], the combination of the directions of the slope of the cross section $L$, the reaction $\boldsymbol{R}$ and the concavity of the 2 nd BM of the rod $[O L)$ in the neighborhood of the support $L$, shown in Fig. 6, $a$, is a sign of the growth of its 2nd CRF with elongation of the rod by attaching a portion to the right and moving the hinge support to the end of the formed rod. The noted growth contradicts to the statement B.

According to the results of [6], equality $\theta_{L}=0$ is the condition for the maximum of the 2nd CRF at elongation, if the setting of a rigid clamp in the cross section $L$ retains $P_{2}$ in the spectrum along with its number, i.e. does not increase the main CRF to $P_{2}$, and the condition of m in im u m or decrease of the 2 nd CRF, if after installing this clamp $P_{2}$ becomes the main.

Since the case of a maximum contradicts statement $B$, equality $\theta_{L}=0$ can only be realized if a rigid clamp at the right end of the rod raises the main CRF to $P_{2}$. This clamp can be considered as the installation of a rigid hinge support in the rod $[O L)$ infinitely close to $L$, whence it follows that this position is optimal, because in all other positions, in the absence of nodes of the 2 nd BM of the rod $[O L)$, a value of CRF equal to $P_{2}$ is not achieved.

Above the restrictions on stiffness $c$ expressed by inequalities were considered. Consideration of boundary values of $c$ is not difficult. Therefore, we restrict ourselves only to the formulating of the corresponding results.

2.5. At $c=P[O L) /|H L|$, there are two positions of the support at which the CRF of the rod $S$ reaches a maximum equal to $P[O L)$. One of them is the right end $L$ of the rod, the second is the point $H$, which in this case is the point of conjugation of the semi-curved BM.

2.6. At $c=P[E L) /|E L|$, the maximum CRF of the $\operatorname{rod} S$ is achieved when the support is installed in the node $A$ of the second $\mathrm{BM}$ of the $\operatorname{rod}\left[O L\right.$ and is equal to $P_{\max }=P_{2}$. This CRF is 2multiple, and two different semi-curved BMs correspond to it (see the remark in section 1.6).

Conclusions. The paper describes the optimal positions of the intermediate support of a two-span rod, providing maximum critical force, depending on the stiffness of its end hinge support. The proposed description is mainly of a qualitative nature and is obtained using mainly qualitative methods. The results obtained make it possible in simple cases, for example, for prismatic rods under standard end support conditions, to find the desired positions and the corresponding critical forces and buckling modes with almost no calculations. In more difficult cases of rods of variable cross-section, they provide reliable guidelines, based on which, it is possible to solve specific optimization problems for compressed rods. The presented results generalize the results of [3], in which both ends of the researched rod were hinged, and pass into them when the clamp stiffness on the support $O$ turns into 0 .

\section{References}

[1] Ya.L. Nudelman, Metody opredelenia sobstvennyh chastot i kriticheskih sil dlya sterzhnevyh sistem. M.-L.: GTTI, 1949. 
[2] Ya.L. Nudelman, D.M. Giterman, S.Ya. Bekshaev, "Vliyanie raspolozheniya uprugih opor na prodol'ny izgib mnogoproliotnogo sterzhnya", Abstract information on the completed scientific research in the universities of the Ukrainian SSR. Structural mechanics and design of structures, Kiev, vol. 7, pp. 18, 1976.

[3] S.Ya. Bekshaev, “Ob optimal'nom raspolozhenii promezhutochnoi opory prodol'no szhatogo sterzhnya", Visnyk Odes 'koi derzhavnoi akademii budivnytstva ta arkhitektury, vol. 60, pp. 400-406, 2015.

[4] S.Ya. Bekshaev, "Poluizognutye formy poteri ustojchivosti i ih ekstremal'nye svojstva", Contemporary problems of natural sciences. Abstr. of 5-th international scientific conference "Tarapov readings", Kharkov, pp. 81-82, 2016.

[5] S.Ya. Bekshaev, "Kachestvennye metody v zadachah povyshenia ustojchivosti szhatyh sterzhnej”, Visnyk kyivs'kogo natsional'nogo universitetu technologij ta dizainu, vol. 3(98), pp. $74-82,2016$.

[6] Bekshaev S.Ya. "O vlijanii dliny sterzhnya na ego kriticheskie sily", Proceedings of the VII International Scientific and Practical Conference "International Trends in Science and Technology», Warsaw, vol. 1, pp. 59 - 64, 2018.

\title{
НАПІВЗІГНУТІ ФОРМИ ВТРАТИ СТІЙКОСТІ ЯК РЕЗУЛЬТАТ ОПТИМІЗАЦЇ̈ СТИСНУТИХ СТЕРЖНІВ
}

\author{
Бекшаєв С.Я. \\ s.bekshayev@gmail.com, ORCID: 0000-0002-5752-5321 \\ Одеська державна академія будівництва та архітектури \\ вул. Дідріхсона, 4, м. Одеса, 65029, Україна
}

\begin{abstract}
Анотація. Розшукуються такі положення внутрішньої абсолютно жорсткої шарнірної опори двопрогінного стержня, при яких його основна критична сила досягає максимуму. Один кінець стержня спирається на абсолютно жорстку опору і має додаткове пружне або абсолютно жорстке защемлення. Протилежний кінець шарнірно обпертий на пружну опору кінцевої жорсткості. Згінна жорсткість стержня змінюється по його довжині за довільним законом. Стискаюча сила у всіх перетинах стержня однакова. У роботі встановлено, що якісна характеризація розшукуваних положень, а також відповідні критичні сили і форми втрати стійкості, залежать від характеристик жорсткості пружних в'язей на кінцях стержня. Визначено три діапазони зміни значень коефіцієнта жорсткості кінцевої опори, яким відповідають якісно різні розв'язки поставленої задачі. Для найнижчого з них оптимальним положенням $\epsilon$ кінець стержня, опертий на пружну опору. Для середнього діапазону оптимальним положенням є проміжний перетин стержня, в якому згинальний момент при втраті стійкості дорівнює нулю. Це положення відокремлює фрагмент, який спирається на пружну опору, який деформується при втраті стійкості, як ізольований стержень, шарнірно опертий по кінцях на абсолютно жорсткі опори. Решта стержня при втраті стійкості залишається недеформованою. Таким чином, при значеннях коефіцієнта жорсткості кінцевої пружної опори 3 середнього діапазону максимально стійкий двопрогоновий стержень втрачає стійкість за особливою напівзігнутою формою. Для третього, вищого діапазону оптимальним положенням є вузол другої форми втрати стійкості стержня, утвореного із розглянутого видаленням проміжної опори. Розшукуваний максимум критичної сили дорівнює другій критичній силі однопрогонового стержня, звільненого від проміжної опори. Результати роботи отримані на основі послідовного використання якісних методів теорії стійкості стержневих систем, зокрема, тих, що відносяться до впливу накладення в'язей на їх критичні сили. Вони можуть бути використані при проектуванні та експлуатації інженерних споруд, які містять стиснуті елементи.
\end{abstract}

Ключові слова: втрата стійкості, стиснутий стержень, напівзігнута форма, оптимізація. 


\title{
ПОЛУИЗОГНУТЫЕ ФОРМЫ ПОТЕРИ УСТОЙЧИВОСТИ КАК РЕЗУЛЬТАТ ОПТИМИЗАЦИИ СЖАТЫХ СТЕРЖНЕЙ
}

Бекшаев С.Я. s.bekshayev@gmail.com, ORCID: 0000-0002-5752-5321 Одесская государственная академия строительства и архитектуры ул. Дидрихсона, 4, г. Одесса, 65029, Украина

\begin{abstract}
Аннотация. Разыскиваются такие положения внутренней абсолютно жесткой шарнирной опоры двухпролетного стержня, при которых его основная критическая сила достигает максимума. Один конец стержня оперт на абсолютно жесткую опору, и имеет дополнительно упругое или абсолютно жесткое защемление. Второй конец шарнирно оперт на упругую опору конечной жесткости. Изгибная жесткость стержня изменяется по его длине по произвольному закону. Сжимающая сила во всех сечениях стержня одинакова. Установлено, что качественная характеристика разыскиваемых положений, а также соответствующие критические силы и формы потери устойчивости, зависят от характеристик жесткости упругих связей на концах стержня. Определены три диапазона изменения значений коэффициента жесткости крайней опоры, которым отвечают качественно различные решения поставленной задачи. Для самого низкого из них оптимальным положением является конец стержня, опертый на упругую опору. Для среднего диапазона оптимальным положением является промежуточное сечение стержня, в котором изгибающий момент при потере устойчивости равен нулю. Это положение отделяет фрагмент, опирающийся на упругую опору, который деформируется при потере устойчивости, как изолированный стержень, шарнирно опертый по концам на абсолютно жесткие опоры. Оставшаяся часть стержня при потере устойчивости остается недеформированной. Таким образом, при значениях коэффициента жесткости крайней упругой опоры из среднего диапазона максимально устойчивый двухпролетный стержень теряет устойчивость по особой полуизогнутой форме. Для третьего, высшего диапазона оптимальным положением оказывается узел второй формы потери устойчивости стержня, образованного из рассматриваемого удалением промежуточной опоры. Разыскиваемый максимум критической силы равен второй критической силе однопролетного стержня, освобожденного от промежуточной опоры. Результаты работы получены на основе систематического использования качественных методов теории устойчивости стержневых систем, в частности, относящихся к влиянию наложения связей на критические силы.
\end{abstract}

Ключевые слова: потеря устойчивости, сжатый стержень, полуизогнутая форма, оптимизация.

Стаття надійшла до редакції 6.02.2020 